International Journal of Engineering \& Technology, $7(2.13)(2018) 155-159$
International Journal of Engineering \& Technology
SPC
Website: www.sciencepubco.com/index.php/IJET
Research Paper

\title{
The land of sushen an early proto-state entity in the far east
}

\author{
Vyacheslav G. Shvedov ${ }^{1}$, Elena V. Stelmah ${ }^{2 *}$, Andrey B. Golub ${ }^{3}$, Tatyana A. Merdeeva ${ }^{4}$, \\ Olesya Ya. Dubey ${ }^{5}$, Sergey V. Nikolaev ${ }^{6}$ \\ ${ }^{1}$ Dr. Sci. (Geography), Associate Professor, Head of the Chair of Geography and Ecology, Sholom-Aleichem \\ Priamursky State University, 70a Shirokaya Street, Birobidzhan, Jewish Autonomous Oblast, 69015 Russian Federation \\ ${ }^{2}$ Elena V. Stelmah, Cand. Sci. (Geography), Associate Professor, Head of the Chair of Customs, Sholom-Aleichem \\ Priamursky State University, 70a Shirokaya Street, Birobidzhan, Jewish Autonomous Oblast, 69015 Russian Federation \\ ${ }^{3}$ Cand. Sci. (Geography), Associate Professor, Head of the Chair of Customs, Sholom-Aleichem Priamursky State University, \\ 70a Shirokaya Street, Birobidzhan, Jewish Autonomous Oblast, 69015 Russian Federation \\ ${ }^{4}$ Cand. Sci. (Education), Associate Professor, Head of the Department of Informational and Industrial Technologies, Sholom-Aleichem \\ Priamursky State University, 70a Shirokaya Street, Birobidzhan, Jewish Autonomous Oblast, 69015 Russian Federation \\ ${ }^{5}$ Head of R\&D and Innovations Division, Sholom-Aleichem Priamursky State University, 70a Shirokaya Street, Birobidzhan, Jewish \\ Autonomous Oblast, 69015 Russian Federation \\ ${ }^{6}$ Ph.D. student, Sholom-Aleichem Priamursky State University, 70a Shirokaya Street, Birobidzhan, Jewish Autonomous Oblast, 69015 \\ Russian Federation, M.A. student, Sholom-Aleichem Priamursky State University, 70a Shirokaya Street, Birobidzhan, \\ Jewish Autonomous Oblast, 69015 Russian Federation \\ *Corresponding authorE-mail: stelmahlena69@mail.ru
}

\begin{abstract}
The region of the Amur River basin and Maritime Territory (Primorye), located within the Russian Federation and the Chinese Peoples Republic, still waits to be deeply explored in order to create a coherent picture of its early historical development. This article is dedicated to the reconstruction of processes related to the establishment by the end of the 3rd or the beginning of the 2 nd millennium $\mathrm{BC}$ and further existence of the union of tribes that lived on this territory, known as the Land of Sushen. We have identified its historical location. We have also compiled a description of the socio-economic and political environment of the Sushen tribes, examined specific characteristics of their ethnic composition and internal organizational structure and have given an assessment of their military capacity and capabilities. On the basis of a consolidated comparison of archaeological data and historical documents, we have analysed the territorial interests of the tribes of the Land of Sushen and their relationships with neighbours in the surrounding geographic areas. We have also disclosed the nature of their relations with ancient China and ancient Korea and explained their specific character. We have reconstructed the causes for the military defeat suffered by the Sushen from Central Asian nomads and its consequences. We have determined their subsequent ethnic heritage in the Amur region and Primorye.
\end{abstract}

Keywords: Archaeological Cultures; the Sushen; Tribal Union; Ancient China; Ancient Korea.

\section{Introduction}

The method of historical reconstruction plays a special role in the cognition of the past [1]. It can be applied when there are some gaps in a particular array of reliable data. In such cases the historical reconstruction is a logical tool allowing researchers to fill in the gaps with the data already available to them. While using this method, two principles should be followed:

- Any reconstruction can only be based on reliable information;

- A "picture" created with its help is hypothetical and is subject to correction each time some new data are obtained on the research subject.

A departure from these principles leads to the creation of false representations having nothing in common with the scientific knowledge [2].

In this article, we use the method of historical reconstruction to recreate the process of formation of the aboriginal tribal union of the Land of Sushen in the region of the Amur River basin and Maritime Territory (Primorye) and their relationships with exter- nal neighbours in end of the 3rd and the beginning of the 2nd millennium BC.

\section{Materials and methods}

When writing this article, we used materials of the field research conducted by the academic staff of the Chair of Geography of the Amur State University named after Sholem Aleichem and results of the studies held in the museums of the cities of Birobidzhan, Khabarovsk, Blagoveshchensk and Vladivostok. We also studied the works of prominent Russian historians, archaeologists and geographers dedicated to the Far East. The results of the conducted studies were systematised with the use of the method of historical reconstruction. In addition, we used the following research methods: field and desk studies, experimental techniques, bibliographical research, spatial analysis and the cartographic method. 


\section{Discussion}

Despite its high methodological value, historical reconstruction is rarely used in research. This could be explained by the fact that it requires strict factual and logical verification of constructs created with its use. Nevertheless, the method of historical reconstruction has been often used by many prominent scholars. Among the most famous foreign researchers, we can name L. Morgan, an American anthropologist of the second half of the 19th century, and A.Toynbee, a British historian of the 20th century. However, the pioneer in the systemic application of historical reconstruction was Russian missionary N.Y. Bichurin, who studied the chronicles of Imperial Archives in Beijing in the 19th century. Among the scholars of the Soviet period who also used the method, it is worth mentioning historians Yu.M. Kobischanov and V. M. Masson. An important contribution to the development of the theoretical foundations for this research method was made by representatives of the socio-economic and historical geography Yu.G. Saushkin and V.K.Yatsunsky.

However, at present the method of historical reconstruction is rarely used in the Far Eastern studies. It is obviously explained by the fact that historical and archaeological research in the region is currently dominated by opponents of the scientific school of Okladnikov, which once held leading positions in these fields of science.

\section{Results}

\subsection{Localization of the land of sushen}

According to the Book of Documents ("Shujing") created in the 9th century, the earliest state of China dates back to 2070 BC. The treatise states that in that year the Xia dynasty was established in the basin of the lower reaches of the Yellow River.

The existence of that state is still a subject of debate. However, nobody disputes the fact that about the specified time near the end of the 3rd millennium BC there was a conglomerate of proto-state formations in this territory [3]. Therefore, we are going to use the term "Xia dynasty" as its generalized conventional name.

Generally speaking, it was an agrarian civilization, which was rather advanced for that epoch, with the rudiments of urban culture [4]. It already had its territorial and political interests and made attempts to defend them. The chronicles describe the nature of its relations with external neighbours, among which the inhabitants of the Amur River basin were named.

"Shujing" and later treatises of "Tszin Shi" and "Huainanzi" state that in the fourth year of the reign of "king" Yu (c. 2021 BC), he was visited by the ambassadors of northern barbarians - the Sushen . They said that their lands were located beyond the Liao River, extending as far north as the valley of the Great River, and to the east - the coast of the Great Sea.

These data allow us to determine the contours of the Land of Sushen. The mentioned Great Sea must have referred to the waters of the Japan and Okhotsk seas. As for the Great River, only one of the rivers of Northeast Asia, which is abounding in water streams, could be worthy of the epithet - the Amur.

Another landmark can be determined based on the Sushen's statement that the centre of their settlement was in the Heavenly Mountains located 1.5 thousand li from the upper reaches of the Liao River. Using the metric equivalent of li in ancient China (576 $\mathrm{m}$ ), we can determine that this ancient toponym stands for the Lesser Khingan mountain range.

So, Sushen settlements were located in the basin of middle and lower reaches of the Amur River with all its tributaries and in the territory of the contemporary Primorsky Krai of the Russian Federation. This is also confirmed by the data found in the treatise "Tszin Shi" of the 2nd century BC, where this entire area is identified as "the ancient Land of Sushen".

\subsection{An effort towards ethnic and linguistic identifica- tion of the sushen}

It is much more difficult to answer another question: what was the origin of the Sushen from the ethnolinguistic perspective? It is not easy to find an answer, because the Sushen society was preliterate, i.e. it did not leave any material evidences which would allow making conclusions regarding the language (or languages) spoken by its representatives. Therefore, we have to refer to the indirect data and the related logical constructs.

In this case one of the instruments of reconstruction can be the materials of archaeological studies. However, one should bear in mind that the results of archaeological studies of the Amur region and Primorye are far from being well-ordered. There are serious disagreements between the schools of archaeologists studying the region over the interpretation of certain findings, as well as identification and periodization of cultures. However, our synthesis of different approaches to this issue allows creating a generalized picture.

At the end of the 3rd millennium BC, the Middle Amur region was the site of the Gromatukha and Novopetrovsk cultures and the Osinovoe Ozero culture, which were all rather similar to each other. The related Lower Amur culture was spread in the territory from the confluence of the Amur and the Ussuri rivers to the Amur estuary, as well as in the northern part of the Sikhote Alin. Their legacy of physical artefacts allows assuming that bearers of those cultures were of mixed ethnic background, which was a combination of more ancient paleo-Asiatic and later Tungusic components

Taking this version as a basis, we can create a logical picture of the Sushen ethnic history. According to our concept, until the 3rd millennium BC the Amur region and Primorye had been populated by ancient Paleo-Asiatics. Later, during the 3rd and the beginning of the 2nd millennium BC this territory was reached by Tungusic migrants from Southern Siberia. Their advance was slow and most likely spontaneous. Consequently, the nature of interaction between those two ethnic groups varied across the territory. A number of settlements dating back to that time were destroyed. However, based on the overall picture, it was a result of local conflicts. The general background of contacts between old-timers and migrants was peaceful, characterized by the processes of assimilation and miscegenation. This version is confirmed by the following:

- Smooth territorial succession of archaeological cultures coexisting along the Amur;

- Equally smooth, gradual decrease of similarities with the cultures of Southern Siberia in their physical legacy when moving from the upper to the lower part of the Amur basin. The elements of regional identity, on the contrary, are increasing in the opposite direction;

- The prevalence of a mixed anthropological type in the human remains attributable to that period;

- Most of the found settlements attributable to that period do not bear traces of destruction.

Against this background, there is a noticeable difference in the archaeological findings in Southern Primorye, where the Zaysanovka culture was spread.

In the 5th-3rd millenniums BC, several "waves" of Austronesian migrants proceeded from the Sunda Islands to the Korean Peninsula and the island of Honshu [5, 6]. A number of artefacts found in Primorye, as well as traces of rice cultivation in this area, indicate that those migrants were the creators of the Zaysanovka culture.

The area occupied by this culture was rather small - from the mouth of the Tumen River to Olga Bay and Lake Khanka. However, its material and cultural influence extended far beyond those limits: certain objects and traces of cult practices found in the Lower Amur were attributed to bearers of the Zaysanovka culture [7-9]. 


\subsection{The level of the technological and economic devel- opment of the Sushen}

In terms of the technological development, all the abovementioned cultures were Neolithic. Meanwhile, some neighbouring societies spread in the area from Trans-Baikal to the Korean Peninsula were already living under Bronze Age conditions. In principle, it is quite easy to explain why the peoples of the Land of Sushen were not casting bronze: an important component of its production is copper, but copper deposits had not been discovered in ancient times, which was a serious limiting factor. At the same time, it looks strange that the Sushen were not acquiring any bronze objects from their neighbours. Only a few foreign bronzes dating from the end of the $3 \mathrm{rd}$ - beginning of the 2 nd millennium $\mathrm{BC}$ have been found in their settlements. At the same time, archaeologists have found a number of items copied from the bronzes, but they are made of a material similar in its properties to slate. There is no explanation for this phenomenon. We can only ascertain the fact that for some reason the Sushen still continued living under Stone Age conditions at the beginning of the 2nd millennium BC.

As for the lifestyle, the characture of the Sushen'settlements in the Middle Amur area and Primorye confirms that they were sedentary. Their largest camping grounds, accommodating 200 to 300 people, were located in the valley of the Songhua River and on the Sea of Japan coast. The settlements in the Amur-Zeya and Middle Amur valleys amounted to $100-150$ people.

The main occupations among the inhabitants of those areas were fishing, hoe agriculture and pig breeding. In Primorye the Sushen were also harvesting and, maybe, also cultivating bivalve molluscs. Populating such a vast territory undoubtedly led to certain economic variations. Fishing was of great importance in the Middle Amur area; to the south of it, the priority was given to agriculture and pig breeding. As for the mollusc harvesting, it was so important for the inhabitants of Southern Primorye that originally the ancient cultures discovered in this area were generally called "the culture of shell middens".

Lower Amur region was inhabited by semi-nomadic communities of 50-100 persons. They were largely based on fishing for their livelihood. For the most of the year they stayed near the river, and only in winter they went up to the watersheds for hunting big game for some period of time. Dogs were the only domestic animals they had.

Mountains to the north of the Amur River and the Sikhote-Alin mountain range were populated by small family groups of nomadic hunters and gatherers adapted to survival in extreme conditions of mountain forests. In general, they had little contact with much more numerous Sushen communities in the river valleys.

\subsection{The territorial activity and military organisation of the Sushen}

With regard to the above, there is an issue that should be clarified: why the Sushen are mentioned in the Chinese chronicles?

As a matter of fact, there is nothing strange in Chinese treatises mentioning one of the "barbarian" tribes. However, there are two peculiarities in this particular case.

The Land of Sushen had no common boundary with the Xia dynasty. They were separated by almost a thousand kilometres. Meanwhile, due to generally poor development of East Asia at that time and difficult access to different territories, external contacts were mainly carried out between the neighbouring societies. As for more remote lands, people had most fantastic views about them, based on circumstantial rumours and speculations. However, the ancient Chinese met the Sushen, who lived almost at the "edge of the Earth".

Another important detail is that the embassies of the "barbarian" Sushen tribes were the first to pay a visit to the "kingdom" of Xia. Meanwhile, initiatives in establishing external contacts were usually taken by ancient China. This was determined by its socioeconomic and technological superiority over its neighbours. How- ever, in this case the Sushen were the initiators of the contact with the Xia dynasty. Their ambassadors explained their visit with the rumours about the rich "country" in the south and the desire to verify that it really existed

This fact creates an image of the Land of Sushen as an active territorial and political entity, seeking for maximum expansion of knowledge about its external environment. However, this conclusion raises new questions. For example, were the Sushen really able to take such actions at the end of the 3rd or the beginning of the 2nd millennium BC? How important were such actions for them?

The following considerations prevent from answering the first of these questions positively:

- The Sushen lacked such an important organizational "core" as the state;

- They still continued living under Stone Age conditions in the Bronze Age environment. In other words, based on formal grounds, they were a backward society.

However, chronicles and archaeological data provide factual evidence to the contrary.

Thus, the Sushen ambassadors said that they "do not have the sovereign", and their tribes were often fighting with each other. But they conducted annual meetings of tribal chiefs in the Heavenly Mountains, where they were looking for ways to resolve internal disagreements and determined a common position in their relations with foreigners.

The Sushen had the most strained relations with the tribes of ancient Korea, which resulted in incessant mutual attacks.

Another object of their constant attention was the mouth of the Amur River, where they regularly made trips for the skins of marine animals, some rare minerals and the amber collected on the Shantar Islands.

The Sushen, living in predominantly agricultural communities, were not interested in the northern taiga-covered ridges of Tukuringra, Dzhagdy and Bureinsky ("the land of darkness"). They often had to repulse raids of Ochazho cannibal tribes coming from that area.

So, the union of Sushen tribes was able both to protect their own territory and manifest some activity beyond its outer perimeter. It is obvious that they had a clear internal organization, which allowed them to carry out such actions. It was an organisation of autonomous tribes that had their own areas of residence, militia forces, traditions and local interests. But there were also some factors that united them.

The first of them was the spiritual unity - the focus of its concentration was their common sacred centre of the Heavenly Mountains. It was obviously the place where common substantive worldview attitudes and cultural and ethical standards of the inhabitants of the Land of Sushen were born and preserved and from where they were further spread.

Another incentive for the integration was external threat. Thus, researchers have not found any traces of trade or cultural exchange between the Sushen and ancient Koreans. This indicates that there were hostile relationships between them. As for the cannibals, peaceful contacts with them were obviously unacceptable in principle.

Consequently, only relying on mutual support, the Sushen tribes were able to defend themselves effectively.

We cannot ignore the reference to tribal chiefs, who were taking important decisions on behalf of the peoples of the Land of Sushen. It indicates that the social organization of the Sushen society corresponded to the stage of military democracy. It is characterised by the growing power of the tribal chief - not yet monarchist, but already functioning as a primary institute of tribe governing. The chief also controlled the tribal military force - a group of professional warriors. As they, in turn, were not engaged in any productive labour, they mainly depended on wars for their livelihoods. Such society, by definition, is oriented to militarization.

Now we want to comment on the representation of the Sushen as a "relict" of the Stone Age. This would presuppose backwardness of 
their weapons and military activities. However, this assessment is far from reality.

Stone weapons were, in general, inferior to metal weapons by their characteristics. But there could a lot of variations against that general background. Thus, in China the stone arrowheads acquired from the Sushen were supplied to arm elite military units. Even in the 5th century BC, when weapons were made of steel, Confucius praised the high quality of Sushen stone arrows.

We have had an opportunity to verify even today that the stone weapons found in the Amur region have an amazing destructive power. We mean the preserved mechanical properties to pierce and cut organic tissue. Therefore, there is no doubt that their lethal capacity was even higher when they were complete with shafts and handles (and in the right hands).

We know nothing about tactical skills of the Sushen and specific features of their military training. However, it was stated in the "Records of Wei", "The Sushen are the most powerful among the eastern barbarians". This description was given in the era when the concept of "power" was associated with only one criterion - the number of victories on the battlefield. It means that the military reputation of the Sushen was rather high.

The Xia dynasty was visited by a few more embassies from the Land of Sushen. Apparently, one of the results of those contacts was the commodity exchange, traces of which have been found both in the Amur region and in the valley of the Yellow River. However, it is impossible to state with absolute certainty that its establishment was the purpose of the mentioned visits. A fairly small number of artefacts can be considered evidence for the trade between the Sushen and the Xia dinasty. This means it was not active. The distance separating them was too great, and journeys were full of danger. At the same time, there were a limited number of goods that could be offered for mutual exchange. However, later events stopped it entirely.

\subsection{The sushen and ancient china}

In the middle of the 2 nd millennium $\mathrm{BC}$, the first historically verified dynasty, the Yin (Shang), took power over ancient China That historical event, in spite of its social-economic and cultural importance, had little impact on the overall political situation in East Asia.

The power of the supreme ruler of the Yin had a purely sacred character. Several hundred "principalities" formally subordinated to the dynasty rulers were actually sovereign entities, and they were all frequently and chaotically at war with each other. Creation and implementation of clear foreign policy doctrines was obviously impossible in such environment.

The Chinese chronicles of that time do not contain any references to the Sushen. Apparently, relationships with them either followed their natural course or had been entirely stopped. But it does not mean that the Sushen disappeared altogether from the world scene. In $1127 \mathrm{BC}$, the Yin dynasty was overthrown by the Zhou tribe, which was ethnically akin to the ancient Chinese. The chronicles say that their tribal chief, known as King Wu of Zhou, created a coalition of more than a hundred of "barbarian" tribes. The Sushen became part of it.

The Yin dynasty was quickly destroyed, but the fight against individual "principalities" lasted over a decade. The Sushen struggled with them in the province of Shandong. It was a difficult theatre of combat operations, with a third party active, besides the Sushen and the Yin defenders - the Yi tribes, who lived on the marshy seaside coast.

They were ethnically alien to the ancient Chinese, and the latter always depicted them in an unfavourable light in their chronicles. That was due to devastating raids by the Yi tribes. They were totally indifferent to the causes, course and result of the dynastic struggle for the power in ancient China. But the chaos reigning in the country created favourable conditions for their predatory raids. So, the "pacification" of Shandong was no easy task. It could only be performed by a well-organized force with an extensive combat experience. The Sushen warriors apparently complied with those requirements, because the Shandong campaign was won, so the winners - the Zhou dynasty - were ready to pay them generously. However, the Sushen looked for another reward.

Attracted by the mild climate and fertile soils of Shandong, they demanded to concede the province to them. It was only with great difficulty that the new Chinese rulers persuaded them to give up the idea. But the appeal of the "warm lands" was too great, and a few years later the Sushen invaded China and went to Shandong. However, that event did not have any serious consequences after all. Obviously, only a part of the Sushen tribes participated in the invasion. Therefore, the Chinese authorities did not consider it a serious threat, and after the first clash at the border, the uninvited visitors were allowed to settle in Shandong.

For several decades, they were mentioned as "nine belligerent tribes" in the Chinese chronicles. Later there were no references to them. Most likely, they were assimilated with the the Chinese population.

\subsection{Decline of the Land of Sushen and its successors}

According to archaeological data, the majority of the Sushen still continued living in their traditional territories. But they experienced hard times. Many of their settlements were destroyed at the end of the 2 nd or the beginning of the 1 st millennium BC. This is an evidence of a serious onslaught of external enemies.

The first of them could be the ancient Kingdom of Joseon, established at the end of the 2nd millennium BC.

According to the Korean historical tradition, Joseon troops reached the Amur River during their military campaigns. However, the accuracy of this statement is questionable. After all, the Great River mentioned in the Joseon chronicles could be the Songhua - the inhabitants of the Korean peninsula had never seen such large watercourses before they reached it. Nevertheless, their pressure on the the Land of Sushen considerably increased. It is evidenced by the artefacts of Joseon origin, including weapons and armour, frequently discovered in the Songhua valley. Besides, it is well known that in 1115 BC China was visited by Sushen embassies, which expressed their appreciation for the start of another war with Joseon.

A true disaster befell the Land of Sushen at the beginning of the 1st millenium BC, when it suffered the invasion of the Donghu nomads from Central Asia.

The wave of invasion skirted the southern slope of the Greater Khingan and reached the Middle Amur, where it spread onto its left bank between the rivers of Zeya and Bira, where the traces of Sushen residence were replaced with the cultural stratum of Central Asian origin. In other words, the Sushen lost most of their arable lands, and many of them died. There were a number of factors that played a role in that defeat.

The demographic and defensive potential of the Land of Sushen had been obviously undermined by the migration of part of the tribes to China. Then the Joseon onslaught resulted in the growth of its military casualties. Finally, the Sushen did not have such combat arms as cavalry.

The Land of Sushen never recovered after such a massive defeat. The Sushen were not mentioned in the Chinese treatises any more during the most part of the 1st millennium BC. However, it does not mean that they disappeared.

At the end of the 3rd century BC, the Qin dynasty defeated the Joseon and occupied the province of Liaoning. The Yilou tribes were found at the new northern boundary of China. They were belligerent inhabitants of the mountain forests. The chronicles say, "The Yilou people have always despised... other powers. All the neighbouring powers suffer from them." Their frequent large-scale raids into the Korean lands were almost always successful and distinguished by extreme cruelty. The Donghu nomads also suffered defeats from the Yilou [10].

The data found in the chronicles have been confirmed by archaeological discoveries. The strata of the Poltse (in the Amur region) and and Krounovka (in Primorye) archaeological cultures, associated with the Yilou, have been rich in findings of stone weapons, 
among which iron items are also found. Some armours and shields made of bones and hooves of animals have been found as well. The settlements dating back to those cultures were located in the strategically convenient places at elevated river bends or the confluence of rivers. They were surrounded with defensive structures. It was not uncommon among early ethnic groups to change their self-designations. As a rule, it happened after some violent upheavals . It was often a consequence of a disastrous military defeat, after which some family group took the lead in consolidating forces to exact revenge. In case of success, their family name was used as a self-designation for the entire "renewed" tribe.

A similar process obviously led to the "transformation" of the Sushen into the Yilou. It was later repeated more than once, owing to which over many centuries there was a continuous chain of transformations from the Yilou through their descendants Mohe into the contemporary Manchus (formerly Jurchen), Udege, Nanai and all sub-ethnic groups of these peoples. Certainly, it was not so straightforward. However, this transformation can be clearly observed, which allows us to state: the earliest known inhabitants of the Amur region and Primorye have not gone into oblivion, and their historical descendants still live in our world today.

\section{Conclusion}

The pre-state union of autochthonous tribes, known as the Land of Sushen, was established in the region of the Amur River basin and Maritime Territory (Primorye) in the end of the 3rd millennium BC. It was formed as a result of common territorial interests and spiritual environment of the area inhabitants. The Land of Sushen was rather active and played an important role in the early political life of East Asia. The union viability depended on their active foreign policy and warlike mentality of the constituent tribes. At the same time, certain aspects of the Sushen life were characterized by sustained conservatism, which ultimately led the tribal union to a military defeat and further decline.

As a conclusion, we can state that our studies have allowed reconstructing the conditions for the formation and existence of the proto-state tribal union of the Land of Sushen in the Amur region and Primorye. Based on the materials of the chronicles and archaeological findings, we have analysed relations of the Sushen with external neighbours in end of the $3 \mathrm{rd}$ and the beginning of the 2nd millennium BC.

\section{References}

[1]. Andreeva Zh.V. Primor'e v jepohu pervobytnoobshhinnogo stroja (Primorye in the Era of Primitive Communism). Moscow: Nauka, 1977, $240 \mathrm{p}$.

[2]. Saushkin Yu.G. Jekonomicheskaja geografija: istorija, teorija, metody, praktika (Economic Geography: History, Theory, Methods and Practice). Moscow: Mysl, 1973, 559 p.

[3]. Nefyodov S.A. Istorija Podnebesnoj (The History of Tianxia). Yekaterinburg: Ural State University Publ., 1992, 168 p.

[4]. Shan Yue. Ocherki istorii Kitaja (Essays on the History of China) Moscow: IVL, 1959, 579 p.

[5]. Wu Chuanjun, Kuo Lai-hsi, Hsieh Hsiang-fang. Jekonomicheskaja geografija kitajskogo Priamur'ja (Economic Geography of the Chinese Amur Region). Moscow: GIGL, 1960, 128 p.

[6]. Shavkunov E.V. Gosudarstvo Bohaj i pamjatniki ego kul'tury v Primor'e (The State of Balhae and its Cultural Monuments in Primorye). Leningrad: Nauka, 1968, 168 p.

[7]. Andreeva Zh.V., Zhuschikhovskaya I.S., Kononenko N.A Jankovskaja kul'tura (The Jankowski Culture). Moscow: Nauka, $1986,215 \mathrm{p}$

[8]. Vorobyov M.V. Kul'tura chzhurchzhjenej i gosudarstva Czin (The Jurchen Culture and the State of Jin). Moscow: Nauka, 1983, 367 p.

[9]. Garkovik A.V. Formirovanie istochnikovoj bazy (Formation of the Source Base). Ocherki pervobytnoj arheologii Dal'nego Vostoka (Essays on Prehistoric Archaeology of the Far East). Ed. by Zh.V. Andreeva. Moscow: Nauka, 1994, pp. 16-24.

[10]. Smolyak A.V. Tradicionnoe hozjajstvo i material'naja kul'tura narodov Nizhnego Amura i Sahalina (Traditional Economy and
Material Culture of the Peoples of the Lower Amur and Sakhalin). Moscow: Nauka, 1984, 246 p. 